\title{
Low Grade Myofibroblastic Sarcoma of the Breast: Case Report and Review of the Literature
}

\begin{abstract}
Herbert Félix Costa1, Adriane Mary Pereira Pimentel ${ }^{2}$, Helen Melo Oliveira ${ }^{3}$, Francisco Hélio Oliveira Júnior ${ }^{4}$, João Kennedy Teixeira Lima5, Francisco Julimar Correia de Menezes ${ }^{6}$, Bruno Moreira Mapurunga7, Bruno Almeida Lessa Castro ${ }^{8}$, Luiz Carlos de Abreu ${ }^{9}$, João Antonio Corrêa ${ }^{10}$
\end{abstract}

\section{Abstract}

Background: Myofibroblastic sarcomas of the breast are rare neoplasms, with aggressive behavior, wich mainly affects individuals 4681 years old, predominantly females. They are malignant tumors composed of myofibroblasts, cells with an important role in inflammatory processes.

Methods and Findings: This study, which was performed at Hospital Geral Waldemar de Alcântara (Waldemar de Alcântara General Hospital) of the city of Fortaleza/Ceará/Brazil, reports a case of myofibroblastic sarcoma of the breast and conducts a literature review on the subject. It is about a female patient, 51, who presented, on the left breast, a mass of rapid growth, which reached about 20 cm (7.9 inches). The diagnosis was confirmed by histology and immunohistochemistry of material obtained by incisional biopsy of the lesion, showing up non-metastatic myofibrosarcoma of the breast. The treatment was simple left mastectomy and adjuvant radiotherapy, with follow-up every six months. Since this type of cancer is rare, treatment is not well established, so more studies are needed on this subject.

Conclusion: The current consensus is the complete excision of the lesion; adjuvant radiotherapy and chemotherapy may be performed. This is one of the few cases of mammary myofibrosarcoma reported in the literature and contributes to the recognition of this rare type of tumor.
1 Thoracic Surgeon afilliated to the InCor/ HC-FMUSP (Heart Institute/University of São Paulo Faculty of Medicine Clinics Hospital).

2 Surgical Oncologist, who works in the gynecological and breast cancer field.

3 Medical Student at Federal University of Campina Grande.

4 Medical Student at Federal University of Ceará.

5 Doctoral Student at ABC Faculty of Medicine; Master professor at Federal University of Campina Grande.

6 Abdominal Surgeon; Professor at Fortaleza University; Coordinator of the Waldemar de Alcântara General Hospital Research Center.

7 Resident Physician of Urology at Walter Cantídio University Hospital.

8 Resident Physician of Surgical Oncology at Ceará Cancer Institute.

9 Scientific Writing Lab of ABC Faculty of Medicine.

10 Surgery Department of ABC Faculty of Medicine.

Contact information:

Joao Kennedy Teixeira Lima.

"= drjoaokennedy@gmail.com

\section{Keywords}

Brain; Neoplasms; Sarcoma;

Breast. 


\section{Introduction}

The term myofibroblastic sarcoma has been described in several ways, as myofibrosarcoma, myofibroblasts sarcoma, myofibroblastic variant of leiomyosarcoma and fusiform cells sarcoma with myofibroblastic differentiation. (GABBIANI et al, 1971).

Low Grade Myofibroblastic Sarcoma of the Breast is a quite rare tumor, with few cases described in literature. (MorgAn PB et al, 2005). They are agressive tumors, which may recur and metastasize. It's occurrence ranges from 46 to 81 years old, and predominate in females.

Differential diagnosis includes benign myofibroblastic lesions, such as nodular fasciitis and fibromatosis; and malign lesions, such as leiomyosarcoma, fibrosarcoma, synovial sarcoma, angiosarcoma and rhabdomyosarcoma of fusiform cells. (FISHER C, 2004).

The gold standard for the diagnosis is electron microscopy. However, it is possible to make the diagnosis of low-grade myofibrosarcoma based on histology and immunohistochemistry. (Morgan PB et al, 2005).

Treatment of this type of tumor is not well established. Currently, the consensus is surgery to remove the complete tumor. (FISHER C, 2004).

\section{Materials and Methods}

\section{Type of study}

This study is a myofibroblastic sarcoma of the breast case report with a literature review on the topic.

\section{Study place}

The study was performed at Hospital Geral Waldemar de Alcântara (Waldemar de Alcântara General Hospital), a secondary care hospital within the public health system of the city of Fortaleza/Ceará/Brazil, which was the first public hospital in the north and northeast of Brazil to receive the title of hospital accreditation level 2 by the National Accreditation
Organization. This is a support hospital for tertiary care network of the State of Ceará, attending only customers of the Sistema Único de Saúde-SUS (Unified Health System). It offers the population 307 beds, distributed in medical, surgical and pediatric clinics, special care unit, adult, pediatric and neonatal intensive care unit. It also develops programs of outpatient and home care, as well as special and personalized care, with multidisciplinary teams to patients with chronic diseases.

The surgical center consists of three operating rooms and a small procedures one. It has modern equipments and quality laparoscopic surgical materials, allowing the performance of 400 surgeries every month. Surgical procedures include various specialties, especially digestive system surgery, surgical oncology, pediatric surgery, urology and head and neck surgery. Surgery service has a general surgery medical residency program, with eight residents, divided into activities in the operating room, surgical ward, outpatient and procedures in ICU.

\section{Population and sample}

Female patient diagnosed with low grade myofibroblastic sarcoma of the breast operated at Waldemar de Alcântara General Hospital in 2011.

\section{Risks and Benefits}

The same risks which are inherent in any major surgical procedure, such as those associated with general anesthesia and the risk of pulmonary thromboembolism due to blood stasis during surgery. In addition, there are the risks of radiotherapy, which is associated with immunosuppression and cell damage caused by radiation. The benefits are the cure of the patient, and the comparison and reproduction of this condition treatment in other medical facilities.

\section{Techniques and data collection instruments}

The study was based on analysis of medical records of the patient diagnosed with low grade myofibro- 
blastic sarcoma of the breast, treated at the outpatient clinic of Waldemar de Alcântara General Hospital.

\section{Case Report}

Female patient, 51, brown, protestant christian, housewife, born in Fortaleza/Ceará/Brazil, coming from Maracanaú/Ceará/Brazil, admitted to the Gynecological Surgery Clinic of Waldemar de Alcântara General Hospital, complaining of lump in the left breast, fast-growing, with onset 4 months ago.

Patient without comorbidities, denied previous surgery, menarche at 13, menopause at 49 years, with no previous pregnancies, denied having undergone hormone replacement therapy or oral contraceptive use. Patient with no family history of cancer. She denied smoking or alcoholism.

On examination, the patient had, on inspection, asymmetrical breasts, with a large mass in the left breast, tractioning the nipple inferiorly. On palpation, left breast with mass of about 20 cm (7.9 inches), hard, with cystic areas, adherence to deep layers, involving all sides, without nipple discharge. Right breast was normal on inspection and palpation. Palpable left axillary lymph node present with a diameter of approximately $1.5 \mathrm{~cm}$ (0.6 inches).

Patient showed mammography having a mixed expansive process, with lobulated contour in the left breast, with volume about 1989, 7cm³, BI-RADS IVa.

Core-biopsy was performed: the result was suggestive of apocrine cyst with surrounding stroma containing chronic inflammation; left breast FNAC (Fine-Needle Aspiration Cytology) was performed as well, whose sample was unsatisfactory. The investigation was continued with a incisional biopsy, and the result was Neoplasm of Fusiform Cells, suggesting complementation with immunohistochemistry. Immunohistochemistry was performed, using the markers present in table 1, showing as result a Low Grade Myofibroblastic Sarcoma.
It was held, then, a simple left mastectomy with resection of the pectoralis major and pectoralis minor preservation without axillary lymph node dissection. Patient recovered uneventfully and was discharged the next day.

Anatomopathological macroscopy (Figures 1-4) described extensive, whitish and firm tumor mass, with rounded edges, measuring $25 \times 18 \times 13 \mathrm{~cm}$. Light microscopy (Figures 5-7), revealed neoplasm composed of fusiform cells, with marked cell den-

Table 1.

\begin{tabular}{ll}
\multicolumn{1}{c}{ Marker } & \multicolumn{1}{c}{ Result } \\
Actin alpha & Diffuse immunostaining in fusiform cells \\
Vimentin & Diffuse immunostaining in fudiform cells \\
Desmin & Diffuse immunostaining in fudiform cells \\
Caldesmon & Diffuse immunostaining in fudiform cells \\
\hline Ki67 & Immunostaining in 69\% of fusiform cells \\
CKpool & Absence of fusiform cells immunostaining \\
\hline S-100 protein & Absence of fusiform cells immunostaining \\
\hline EMA & $\begin{array}{l}\text { Absence of fusiform cells immunostaining; } \\
\text { focal immunostaining in a blood vessel }\end{array}$ \\
\hline CD34 & Absence of fusiform cells immunostaining \\
\hline CD117 & Absence of fusiform cells immunostaining \\
BCl2 & Absence of fusiform cells immunostaining \\
\hline ER & Absence of fusiform cells immunostaining \\
PR & Absence of fusiform cells immunostaining
\end{tabular}

\section{Figure 1.}

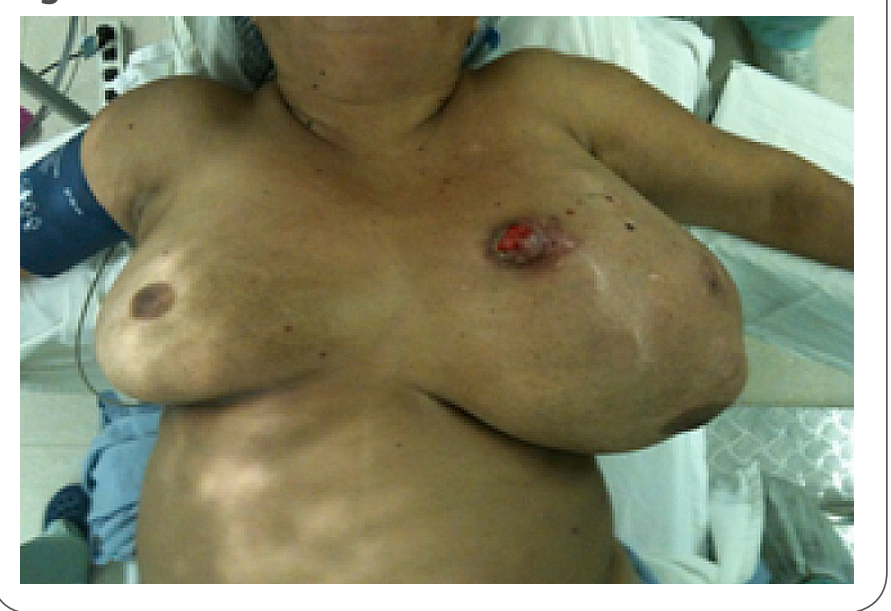




\section{Figure 2.}

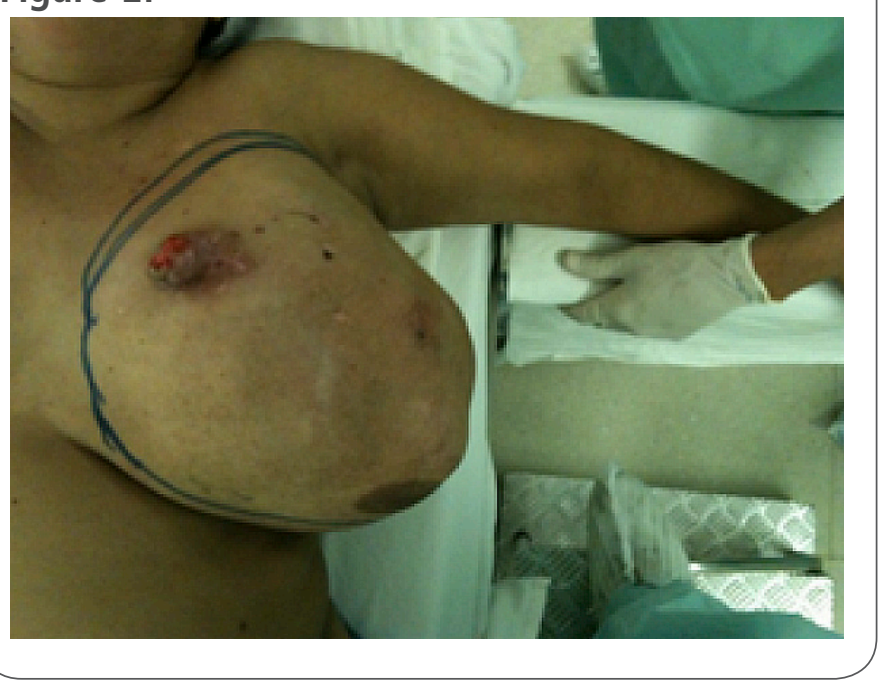

Figure 3.

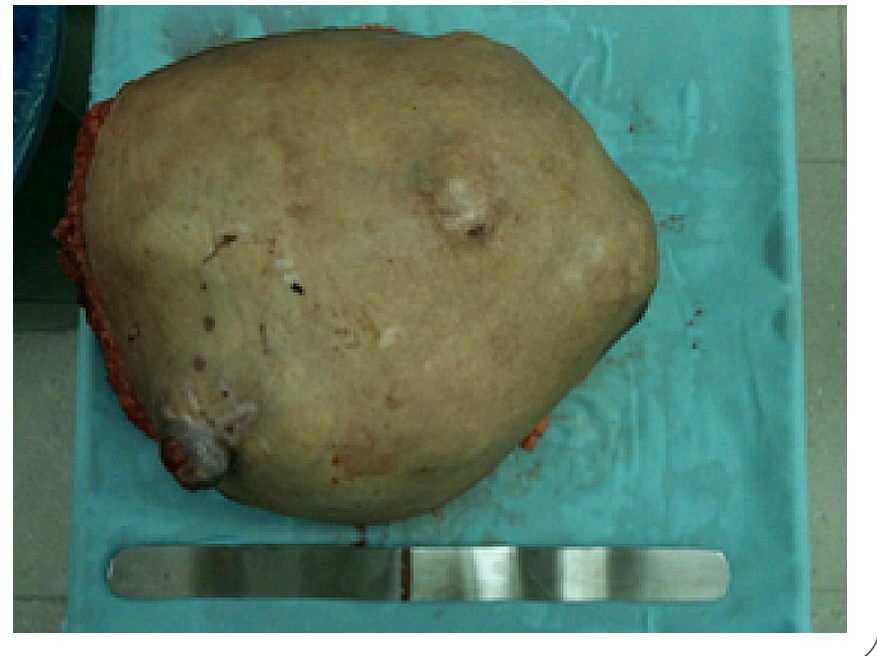

Figure 4.

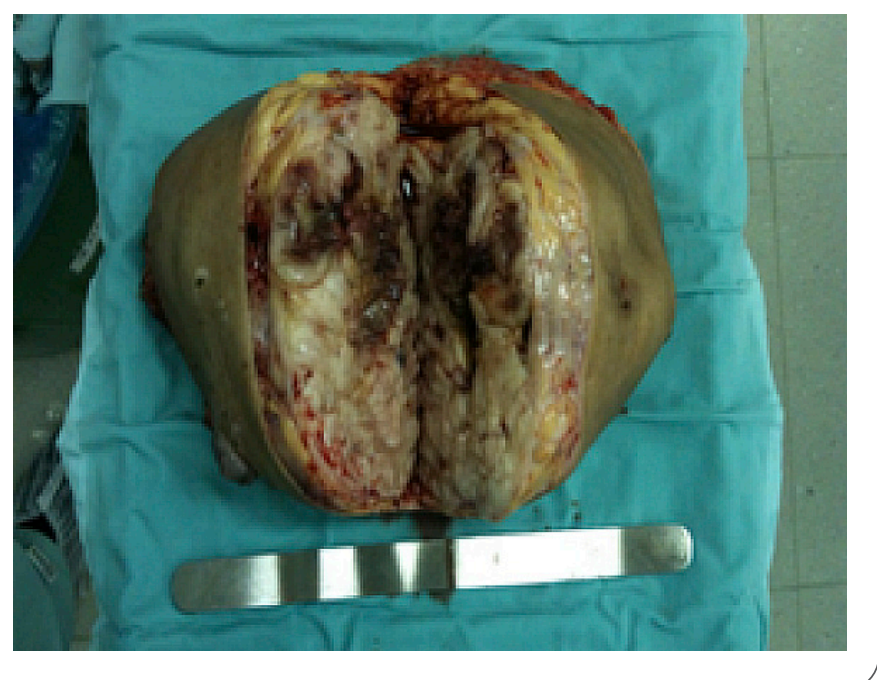

Figure 5.

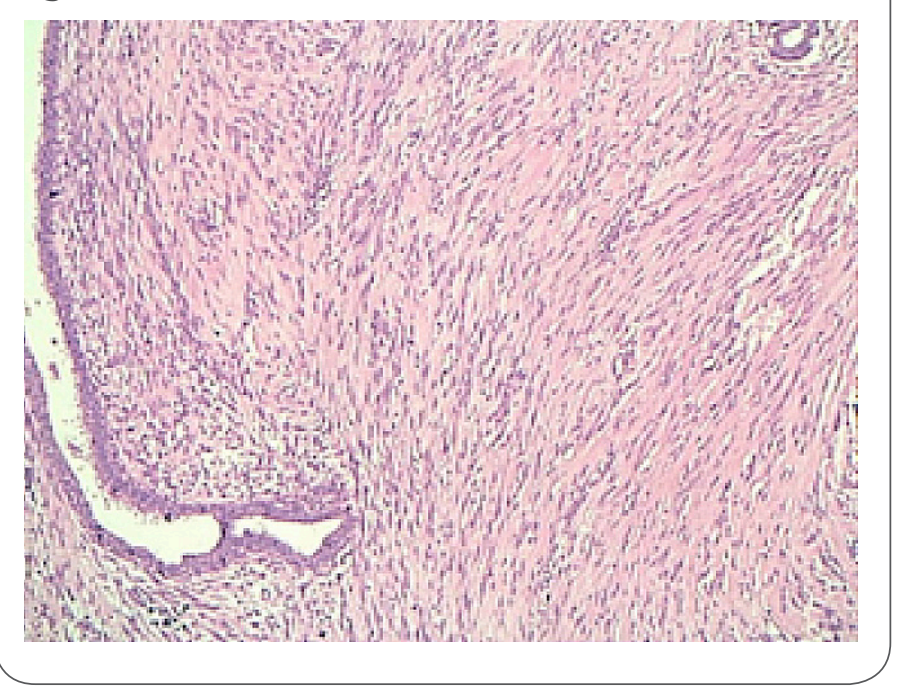

\section{Figure 6.}

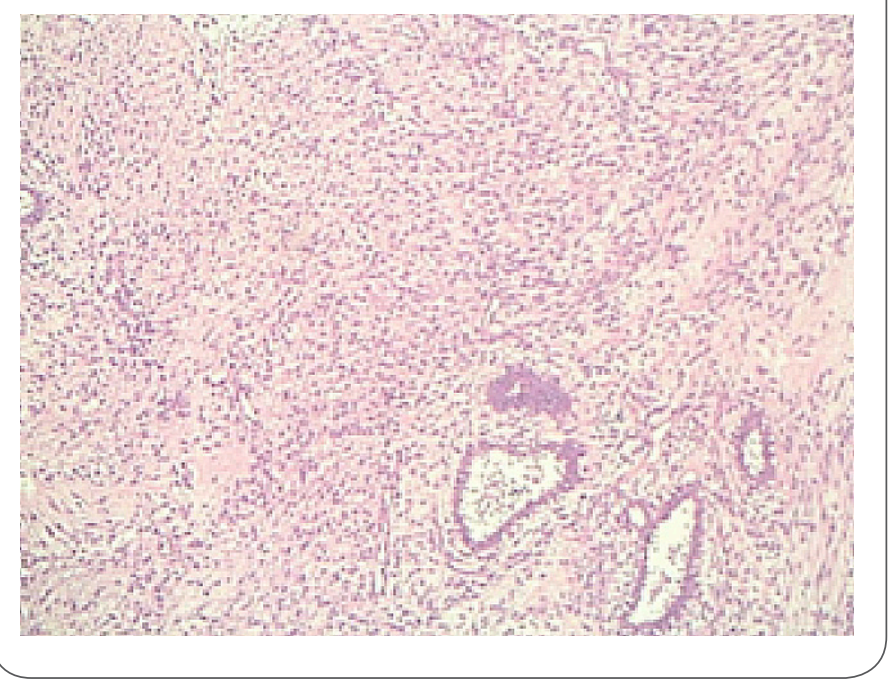

\section{Figure 7.}

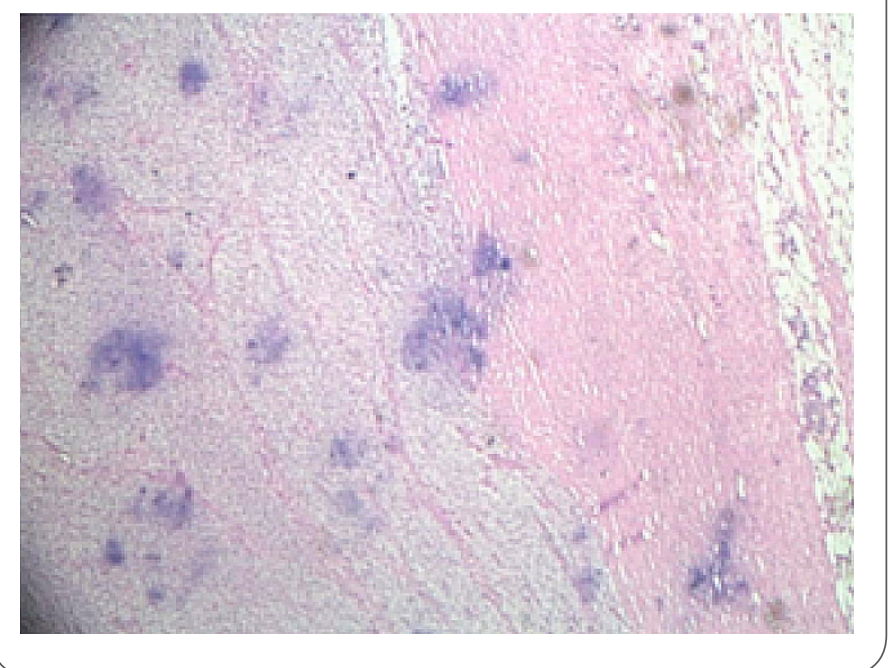


sity, light to moderate cell pleomorphism, 23 mitosis/10 HPF (High Power Field), arranged at random and short beams, in collagenous matrix, with hyaline collagen bands, myxoid hypervascular areas and foci resembling bone metaplasia; in part of the lesion, it was observed association with glandular, tubular e rarely foliaceous elements, with epithelial lining without atypia; areas of necrosis, of infiltration of the mammary fat, of the dermis and epidermis ulceration; surgical margins free of tumor; histologically normal nipple. The result of the pathological examination was phyllodes malignant tumor with sarcomatous transformation of low-grade myofibroblastic type, affecting skin, measuring $25 \times 18 \times 13 \mathrm{~cm}$.

The treatment was complemented with radiotherapy, with total dose of 6.000 cGy. Patient has six-month follow-up, performing mammography, breast ultrasound and right chest radiography without presenting, so far, signs of recurrence or metastasis.

\section{Discussion}

Myofibroblasts were first described in the 70's, when theywere founds in granulation tissue, and it was believed to be "modified fibroblasts". (GABBIANI et al, 1971). They are important components for the repair of damaged tissue and appear after the end of the initial inflammatory phenomena. (GABBIANI et al, 1971).

Correspond histologically to fusiform cells with a pale eosinophilic cytoplasm, with irregular borders, and, depending on their function, feature elongated nucleus or, sometimes, a little wavy. They have finely dispersed chromatin or grouped in a cylindrical shape, partially notched, or spindle-shaped, often with visible eosinophilic nucleoli. (SKalu et al, 1989).

They also interact with the extracellular matrix through fibronexus, which are complex transmembrane intracellular microfilaments in apparent con- tinuity with extracellular fibronectin fibers. (LOPES, 1999).

The immunohistochemical characterization of myofibroblasts, as in other eukaryotic cells is based on the analysis of three systems of contained proteins in the cytoskeleton, (Fuchs e Cleveland,1998), wich are: a) actin microfilaments; b) intermediate filaments of vimentin, desmin, laminin, glial fibrillary acidic protein (GFAP); c) $\alpha$ and $B$ tubulin of microtubules (which have not been characterized with regard to tubulin subtypes). Actin microfilamentsare presentsin all kinds of cells, andall fibroblasts express as actins F, $B$ and $\gamma$. In myofibroblasts, besidesthoseactins, there is important expression of proeminent cytoplasmic microfilaments of $\alpha$-smooth muscle actin ( $\alpha$-SMA). (TOMASEK et al, 2002).

Besides the presence $\alpha$-SMA, which distinguishes myofibroblasts, there have been attempts to classify them using intermediate filaments, such as vimentin and desmin (Mermall et al, 1998), but these proteins expression may vary according to the studied tissue physiopathological conditions, species and other environmental factors, such as: the cells are studied in situ or in vitro, in the same tissue, or cells are activated by a chemical messenger or by the effect of some pathogenic process. (Powell et al, 1999).

Through immunohistochemical studies of these filaments, myofibroblasts can be classified as the following subtypes (SchimitT-GrafF et al, 1994): 1) those which express only vimentin are called type $\checkmark$ myofibroblasts; 2) those which express vimentin and desmin are type VD; 3) those which express vimentin, $\alpha$-SMA and desmin are called type VAD; 4) those which express vimentin and $\alpha$-SMA are type $V A$; e 5) those which express vimentin and myosin are type VM. (ABRAHAM, 2004).

Besides having contractile forces, myofibroblasts have the property to synthesize collagen of various types, such as types I, III, and IV. In healing wounds granulation tissue myofibroblasts are especially nu- 
merous and the main type of collagen produced is type III, giving a degree of plasticity to injury in the early stages of healing. When granulation tissue is reabsorbed and occurs the wound closure, myofibroblasts disappears and, from the biochemical point of view, type I collagen is predominantly identified. Type $V$ collagen is easily biochemically identified in desmoplastic breast carcinomas and it appears to be produced by myofibroblasts. (FreItAS, 1988).

In 1979, the presence of myofibroblasts in the stroma of mammary carcinomas has been described, making skin thickening and retraction. Myofibroblasts are not normally found in breast stroma, which suggests that these cells contribute to retraction and desmoplasia, characteristics of these carcinomas. (Tremblay et al, 1979).

In sarcomas, myofibroblasts usually constitute a small fraction of the cell population. They are clearly identified in all cases of malignant fibrous histiocytomas and of sclerosing variant of well-differentiated liposarcoma. (Ghadially et al, 1983). Although they show quite numerous at areas of desmoplasia, in the cited examples, myofibroblasts are not the dominant elements of any of these cell malignancies. Myofibroblasts have been identified less frequently and in smaller numbers in fibrosarcomas, synovial sarcomas, malignant hemangiopericytomas and neuroblastomas. (Seemaier et al, 1980).

Studies about leiomyosarcomas have found that these tumors are very heterogeneous, and that the use of markers for cytoskeletal proteins, such as alpha-actin and desmin, are useful for identifying cell types present in the stroma of tumors, including myofibroblasts. Myofibroblasts are also present in uterine plexiform tumors and in cardiac myxomas. (SCHÜRCH et al, 1987).

The term "myofibrosarcoma" was first used to describe myofibroblast malignant tumor by Ghadially in 1980. (Ghadially FN, 1980). Myofibroblast malignant tumors can be grouped according to Table 2.
Table 2.

\section{Myofibroblastic sarcomas}

Low-grade

Myofibrosarcoma

Inflammatory myofibroblastic tumor

Infatile fribrosarcoma (including cellular congenital mesoblastic nephroma)

Intermediate-grade

Myofibrosarcoma

High-grade

Pleomorphic Myofibrosarcoma

Other malignant tumors with myofibroblastic differentiation

Dermatofibrosarcoma ("myoid" areas) (questionable)

Epithelioid sarcoma

Spindle-cells carcinoma

Myofibroblastic Malignancies. Fisher, Cyril; MD, DSC. Advances in Anatomic Pathology. 11(4): 190-201, July, 2004

Low-grade myofibroblastic sarcoma is a differentiated tumor, for which it was classified as a different type of sarcoma or mistaken for tissue reaction to injury. There are reports of this type of tumor in soft tissues and bones as a fasciitis or fibrosarcomalike of fusiform cells that infiltrates locally, but it rarely metastasizes. Stiller and Katenkamp mentioned myofibroblasts in well-differentiated fibrosarcomas in 1975, (Stiller D et al, 1975) and Vasudey and Harris reported the first "myofibroblasts sarcoma" three years later. (VASUDEV KS, 1978).

Low grade myofibrosarcomas may be located on the skin or submucosa, but may also develop in the deeper layers of tissues. (Montgomery E et al, 2001, KUHNEN $C$ et al, 2003).

In the following 20 years since the first report of myofibrosarcoma, only have been described low and medium grade myofibrosarcomas in 6 adults and in 6 children as simple case reports (D'ANDIRAN $G$ et al, 1980, EYden BP et al, 1972, TACCAGNI $G$ et al, 1997) and in 2 small case report series. (SмIтH 
DM et al, 1995, EYDEN BP et al, 1991). All but 2 cases, developed in the head and neck, in soft tissue (post-auricular region, face, tonsils, scalp, neck and thyroid) and in bone tissue (maxilla and mandible). Other 3 examples were included in a study of 200 soft tissue sarcomas in adults. (FIsHer C, 1990).

Most myofibrosarcomas is positive for actin and less than half of them express desmin, usually in a few cells. These antigens can be expressed together or separately, with imunophenotype desmin-positive/SMA-negative or, more often, desmin-negative/ SMA-positive (Mentzel T et al, 1998). The SMA staining can be differentiated, at least focally, as a peripheral halo below the cell membrane. Furthermore, calponin is diffusely positive in most cases, while hcaldesmon is detected as a focal expression in a few cases (FISHER $C$ et al, 2003). These findings, which are similar to nodular fasciitis, are extremely useful in the differentiation of leiomyosarcoma, which usually expresses both h-caldesmon as calponin. Some myofibrosarcomas express fibronectin (EYDEN BP et al, 1993), but not laminin or type IV collagen. Cytokeratin and EMA (Epithelial Membrane Antigen) are rarely positive, and rare myofibrosarcomas focally exhibit CD34. (Mentzel T et al, 1998).

Among the 39 cases published with tracking information, there were 13 (33\%) recurrences and 3 (8\%) had metastasized. In one of the series of 11 patients, 2 low-grade myofibrosarcomas resorted (1 appealed by 2 times), and 1 resulted in metastasis. (Mentzel T et al, 1998). In another study, 4 of 8 low grade tumors and 3 of 4 medium grade tumors recurred (1 resorted 2 times), and 1 patient with medium grade breast tumor has developed lung metastasis after 12 months. (Montgomery $\mathrm{E}$ et al, 2001). Myofibrosarcomas may resemble myofibroblastic benign lesions such as nodular fasciitis, and fibromatosis.

Differential diagnosis includes other fusiform cell sarcomas such as synovial sarcoma or nerve sheath tumor, as well as some examples of angiosarcoma and rhabdomyosarcoma of fusiform cells (FISHER C,
2004), and others subtypes of sarcoma, especially leiomyosarcoma and fibrosarcoma. Besides that, myofibrosarcomas may resemble myofibroblastic benign lesions such as nodular fasciitis, and fibromatosis,

Nodular fasciitis typically appears suddenly and has rapid growth. Generally, does not exceed $5 \mathrm{~cm}$ (2 inches) in diameter and is located in subcutaneous tissue. There is a zoning with fibrotic, myxoid and cellular areas in different parts of the same injury, nuclear atypia and necrosis are absent. Myofibrosarcoma has more cells and it is more uniform than nodular fasciitis and infiltrates deeper, including skeletal muscle and bone. Fibromatosis infiltrates skeletal muscle, showing muscle fiber atrophy instead of separation by the tumor, as a myofibrosarcoma does. There are myofibroblasts parallelly aligned, dispersed in a dense collagen with blood vessels and mast cells, and cytological atypia is absent.

Some myofibrosarcomas resemble leiomyosarcomas. These, however, have typically fascicles of cells that are less conical and core bordered by perinuclear vacuoles. Furthermore, there is greater expression of h-caldesmon.

Adult-type fibrosarcoma, by contrast, has a fascicular architecture with herringbone provision and cells with scant cytoplasm and nuclei of elongated cone shape. There is usually more intracelular collagen than in myofibrosarcoma. In some cases (including fibrosarcomas resulting in dermatofibrosarcoma and solitary fibrous tumor) it is CD34 positive, but immunohistochemical markers of myoid differentiation are absent.

Extra-mammary myofibrosarcomas tend to have a more indolent course, although they may recur and metastasize. However, mammary myofibrosarcomas are more agressive.

It were not identified invasion or lymphatic metastasis in any of the cases described, suggesting that metastasis of myofibrosarcoma of the breast is made through the blood stream. Unlike extramammary myofibrosarcomas, which infiltrate irre- 
gularly, myofibrosarcomas of the breast can be partially circumscribed and well defined, as seen in macroscopic description of this case report. (STARK $M$ et al, 2011).

The gold standard for the diagnosis of low-grade myofibrosarcoma is electron microscopy, which demonstrates specialized organelles called fibronexus joints and fibronectin fibrils that connect the myofibroblast to the extracellular matrix. However, it is possible to make the diagnosis of low-grade myofibrosarcoma based on histology and immunohistochemistry, and differentiate it from leiomyosarcoma and malignant fibrous histiocytoma. Immunohistochemistry shows the myofibrosarcoma positive for $\alpha$-actin and vimentin, while leiomyosarcoma shows positive only for $\alpha$-actin, and malignant fibrous histiocytoma is shown only positive for vimentin. As the metaplastic sarcoma, another differential diagnosis, it is shown negative for $\alpha$-actin and may or may not be positive for vimentin. (MoRGAN PB et al, 2005).

Treatment of this type of tumor is not well established. The consensus for the treatment is surgery to remove the complete tumor. (FISHER C, 2004). Radiation therapy and chemotherapy may assist in the surgery post-operative (STARK $M$ et al, 2011) or should only be used in cases of inoperable, recurrent or metastatic tumor. (FISHER C, 2004).

Therefore, because it is an aggressive tumor, diagnosis and early treatment are essential for the prognosis of patients who have this disease. The case described in this paper is one of the few reported and contributes to the recognition of this rare disease.

As a limitation of this study, we may list the precarious conditions of the brazilian public health system, Sistema Único de Saúde (Unified Health System), as the patient had to wait a long time for being operated. Because of this, her surgery was made when the tumor already had grown up a lot.

\section{References}

- Gabbiani G, Ryan Gb, Majno G: Presence of modified fibroblasts in granulation tissue and their possible role in wound contractions. Experimentia 27: 549-550, 1971.

- Tremblay, G. Stromal aspects of breast carcinoma. Exp. Mol. Pathol., v 31, p248-260, 1979.

- Skalli O, Schürch W, Seemayer T, Lagace R, Montandon D, Pittet B, Gabbiani G: Myofibroblasts from diverse pathologic settings are heterogeneous in their content of actin isoforms and intermediate filament proteins. Lab Invest 60: 275-285, 1989.

- Tomasek, J. J.; Gabbiani, G.; Lins, B.; Chaponnier, C.; Brown, R.: Myofibroblast and mechanoregulation of connective tissue remodeling. Nature Rev. Mol. Cell. Biol., v 3, p 349-363, 2002.

- Lopes, L.A. Análise in vitro da Proliferação Celular de Fibroblastos de Gengiva Humana Tratados com Laser de Baixa Potência. Dissertação apresentada ao Instituto de Pesquisa e Desenvolvimento da Universidade Vale do Paraíba como parte dos requisitos para obtenção do título de Mestre em Ciências, do Curso de Pós-Gradução em Engenharia Biomédica. Orientador: Prof. Dr. Renato Amaro Zíngaro Co-orientador: Prof. Dr. João GuidugliNeto, São José dos Campos, SP, 1999.

- Fuchs, E. Cleveland, D.W.A structural scaffolding of intermediate filamentsin health and disease. Science, v 279, p 514-519, 1998.

- Mermall V.; Post, P.L.; Mooseker, M.S. Unconventional myosins in cell movement, membrane traffic, and signal transduction. Science; v 279, p 527-533, 1998.

- Powell, D. W.; Mifflin, R. C.; Valentich, J. D.; Crowe, S. E.; Saada, J. I.; West, A. B. Myofibroblasts. Paracrine cells important in health and disease. Am. J. Physiol., v 277: 1-19, 1999.

- Schmitt-Graff, A.; Desmouliere, A.; Gabbiani, G.. Heterogeneity of myofibroblast phenotypic features: an example of fibroblastic cell plasticity. Virchows Arch., v 425, p 3-24, 1994.

- Abraham C.R.; et al. El miofibroblasto, uma célula multifuncional em La Patologia Pulmonar. Rev. Inst. Nal. Enf. Resp. Mex., México, v.17, n3, p 473-479, 2004.

- Freitas, L. A. R. Fibrogênese e diferenciação celular (Estudo histológico, ultraestrutural e imuno-citoquímico com o modelo do bolsão inflamatório de Selye, em ratos). 1988. 162 f. Mestrado (Dissertação em Patologia Humana)- Universidade Federal da Bahia, Salvador

- Ghadially, F. N.; Mcnaughton, J. D.; Lalonde, J. M. Myofibroblastoma: a tumor of myofibroblasts. J. Submicrosc. Cytol., v15, p 1055-1063, 1983. 
- Seemayer, T. A.; Lagacè, R.; Schürch, W I. On the sclerosis and nodularity in nodular sclerosing Hodgkin's disease. Virchows Arch., v 385, p 283-291, 1980.

- Schürch, W.; Skalli, O.; Seemayer, T.A.; Gabbiani, G. IntermediateFilament Proteins and Actin Isoforms as Markers for Soft Tissue TumorDifferentiation and Origin. Am. J. Pathol., v 128, p 91-103, 1987.

- Ghadially FN. Diagnostic Electron Microscopy of Tumours. London: Butterworths; 136, 1980.

- Stiller D, Katenkamp D. Cellular features in desmoids fibromatosis and well-differentiated fibrosarcomas: an electron microscopic study. Virchows Arch A Pathol Anat Histol. 369: 155-164, 1975.

- Vasuder Ks, Harris M.A sarcoma of myofibroblasts. An ultrastructural study. Arch Pathol Lab Med. 102: 185-188, 1978.

- D'andiran G, Gabbiani G. A metastasizing sarcoma of the pleura composedofmyofibroblasts. Prog Surg Pathol. 2: 31-40, 1980.

- Eyden Bp, Christensen L, Tagore V, et al. Myofibrosarcoma of subcutaneous soft tissue of the cheek. I Submicrosc Cytol Pathol; 24: 307-313, 1972.

- Taccagni G, Rovere E, Masullo M, et al. Myofibrosarcoma of the breast: review of the literature on myofibroblastic tumors and criteria for defining myofibroblastic differentiation. Am J Surg Pathol. 21: 489-496, 1997.

- Smith Dm, Mahmoud Hh, Jenkins JJ 3RD, et al. Myofibrosarcoma of the head andneck in children. Pediatr Pathol Lab Med. 15: 403-418, 1995.

- Eyden Bp, Banerjee Ss, Harris M, et al. A study of spindle cell sarcomas showing myofibroblastic differentiation. Ultrastruct Pathol. 15: 367-378, 1991

- Fisher C. The value of electronmicroscopy and immunohistochemistry in the diagnosis of soft tissue sarcomas: a study of 200 cases. Histopathology. 16: 441-454, 1990.

- Morgan Pb, Chundru S, Hatch Ss, Hawkins Hk, Adegboyega Pa, And Eltorky MA. Low-Grade Myofibroblastic Sarcoma of the Breast. Journal of Clinical Oncology. 25: 6249, 2005.

- Mentzel T, Dry S, Katenkamp D, et al. Low-grade myofibroblastic sarcoma: analysis of 18 cases in the spectrum of myofibroblastic tumors. Am J Surg Pathol. 22: 1228-1238, 1998.

- Montgomery E, Goldblum Jr, Fisher C. Myofibrosarcoma: a clinic pathologicstudy. Am J Surg Pathol. 25: 219-228, 2001.

- Kuhnen C, Homann Hh, Mentzel T. [Myofibroblastic sarcoma of the thoracicwall. Change in appearance in tumour recurrence]. Pathologe. 24: 128-135, 2003.

- Fisher C, Goldblum Jr, Montgomery E. Calponin and h-caldesmon in sarcomas ofmyofibroblasts. Mod Pathol. 16: 11A, 2003.
- Eyden Bp, Christensen L. Leiomyosarcoma versus myofibrosarcoma: observationsand terminology. Ultrastruct Pathol. 17: 231-239, 1993.

- Fisher C. Myofibroblastic Malignancies. Advances in Anatomic Pathology. 190-201, 2004

- Stark M, Hoffmann A, Xiong Z. Mammary Myofibrosarcoma: Case Report and Literature Review. The breast Journal. 3: 300304, 2011.

- Taccagni G, Rovere E, Masullo M, et al: Myofibrosarcoma of the breast: Review of the literature on myofibroblastic tumors and criteria fordefining myofibroblastic differentiation. Am J Surg Pathol 21: 489-496, 1997.

\section{Comment on this article:}

\section{(f) $[$ in $8+\boldsymbol{S}$.}

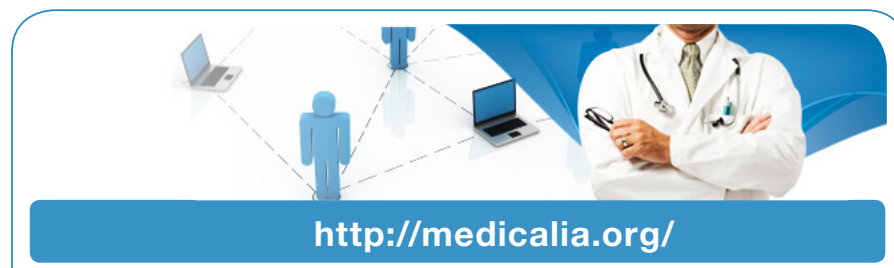

Where Doctors exchange clinical experiences, review their cases and share clinical knowledge. You can also access lots of medical publications for free. Join Now!

\section{Publish with iMedPub}

\section{http://www.imed.pub}

International Archives of Medicine is an open access journal publishing articles encompassing all aspects of medical science and clinical practice. IAM is considered a megajournal with independent sections on all areas of medicine. IAM is a really international journal with authors and board members from all around the world. The journal is widely indexed and classified Q1 in category Medicine. 